\title{
ARTEFATOS DE ÉPOCA E O NOVO ROMANCE HISTÓRICO BRASILEIRO - UMA POSSÍVEL MUDANÇA CULTURAL DO PÚBLICO LEITOR ${ }^{1}$
}

\section{TIME ARTIFACTS AND THE NEW BRAZILIAN HISTORICAL NOVEL - A POSSIBLE CULTURAL CHANGE IN THE READER PUBLIC}

\author{
Cristiano Mello de Oliveira*
}

Resumo: Nas duas primeiras décadas do século XXI, tem-se notado um gosto comum entre os diversos tipos de leitores: a busca por compreender a História do Brasil através de romances históricos e livros de divulgadores de fatos recentes ou não. Esta predileção de leitura por meio deste subgênero literário também se relaciona com a compra e a aquisição de artefatos produzidos pela chamada Indústria Cultural que denomino de moda nostálgica. Calculo que a preferência não é fortuita, pois muitos leitores no Brasil encontram nesse estilo literário uma forma de fugir dos problemas cotidianos, conforme aponta a crítica. A presente pesquisa averigua em que medida a aquisição de alguns artefatos de época se relaciona com a leitura de romances históricos. Como balizamento teórico, cada qual ao seu modo, utilizarei os autores: HUYSSEN (2000), SARLO (2010), BURKE (1994), FLECK (2017), OLIVEIRA (2016), dentre outros. Objetivo deixar como contributo algumas considerações a respeito deste novo modelo de consumo de conhecimento do passado, identificando algumas possíveis razões de motivação dos leitores.

Palavras chave: Artefatos de época; Novo Romance Histórico Brasileiro; Interesse e motivação do público leitor.

ABSTRACT: In the first two decades of the twenty-first century, there has been a common taste among the various types of readers: the search for understanding the history of Brazil through historical novels and books of popularizers of recent events or not. This predilection for reading through this literary subgenre is also related to the purchase

\footnotetext{
${ }^{1}$ Gostaria de realizar os meus devidos agradecimentos pela interlocução e sugestões propostas pelo professor Dr. Francisco Gilmei Fleck (Unioeste-PR) e a jornalista Ana Cláudia.

"Pós-doutorando em Letras Vernáculas pela UFRJ. Doutor em Letras pela Universidade Federal de Santa Catarina. E-mail: crisliteratura@yahoo.com. Autor da tese: “O Novo Romance Histórico brasileiro em travessias: A República dos Bugres e Conspiração Barroca, de Ruy Reis Tapioca”. A pesquisa foi defendida em agosto de 2016. Com leves alterações, acréscimos e novos argumentos, o texto deste artigo é um recorte da tese citada.
} 
and acquisition of artifacts produced by the so-called Cultural Industry that I call nostalgic fashion. I estimate that the preference is not fortuitous, since many readers in Brazil find in this literary style a way of escaping from daily problems, as critics point out. This research examines the extent to which the acquisition of some period artifacts relates to the reading of historical novels. As a theoretical beacon, each in its own way, I will use the authors: HUYSSEN (2000), SARLO (2010), BURKE (1994), FLECK (2017), OLIVEIRA (2016), among others. Aim to leave as contribution some considerations about this new knowledge consumption model of the past, identifying some possible reasons motivation of the readers.

KEYworDs: Period artifacts; New Brazilian Historical Romance; Interest and motivation of the reading public.

\section{Alguns pressupostos:}

A história é o nosso referencial perdido, isto é, o nosso mito. (Jean Baudrillard)

Em tese de doutorado, defendida em agosto de 2016, estabeleci uma espécie de conceito intitulado "Motivação do público leitor por romances históricos", do qual me ocupei em identificar as múltiplas razões de curiosidade por parte do leitorado brasileiro pelo consumo de romances históricos na recém-atualidade ${ }^{2}$. Nesta expressão autoexplicativa residia uma série de fatores que buscavam fundamentar o meu argumento: o que pesava no pensamento dos leitores (assíduos ou não necessariamente de romances históricos) quando assumiam o compromisso de leitura. Reforço que este tema ainda muito me fascina - e continuo buscando novas formulações que partam desta premissa. Nas linhas iniciais da minha pesquisa, busco atestar por meio dos anexos formulados pelos estudiosos Esteves (2008); Weinhardt (2015); Menton (1993) como a quantidade de romances históricos cresceu exponencialmente, favorecendo a formação de um grupo leitor específico. Ainda na introdução, faço uma articulação sobre as possibilidades de compreender os fatos históricos pela leitura de narrativas do gênero

${ }^{2} \mathrm{O}$ espaço temporal que abranjo na minha investigação (realizada parte na minha tese de Doutoramento, conforme referências no fim do artigo) se situa entre os anos de 1990 a 2016, data de publicação da minha recente pesquisa. Portanto, é por meio deste lastro temporal que abarcarei também o relançamento de alguns produtos nostálgicos citados. 
ou subgênero ${ }^{3}$, ampliando os variados ângulos do leitor por um viés mais dramatizado e pouco convencional aos livros dos historiadores, conforme defendia o autor Nicolau Sevcenko 4 .

Na verdade, leituras e reflexões recentes vêm sendo observadas com o objetivo de dizer que a sociedade moderna mantém um forte apelo memorialístico e museológico ${ }^{5}$ sem, no entanto, alimentar que alguns "artefatos de época" podem constituir uma possível interface com a aquisição e a leitura de romances históricos, o que serviu de hipótese para analisar tal questão. Objetos de uma determinada época ou de grupos de outras gerações tornam-se, a meu ver, cruciais para diagnosticar um crescente interesse pelos fatos pretéritos. Não é à toa que nas considerações finais da minha pesquisa de Doutorado, retomo brevemente alguns resultados alcançados - interrogando aqueles que não foram suficientemente explorados: o consumo e o fenômeno mercadológico da memória e as lembranças nostálgicas massivas que se entrelaçam pela conexão com o romance de natureza histórica. ${ }^{6}$ Por uma perspectiva desdobrada, longe de repetir e parafrasear os argumentos utilizados na redação da minha recente pesquisa, parto para retrabalhar novas propostas, novos autores e referências, assim como argumentos para esta respectiva análise.

A presente intervenção expõe quais são as principais causas e motivações da busca pela leitura de romances históricos, simulando uma possível interface com alguns artefatos de época. O problema desta exposição é tentar romper o paradigma obsoleto da crítica vigente (tida como uma espécie de chavão reducionista), o qual estabelece que muitos leitores de romances históricos procurem apenas fugir dos problemas do cotidiano, designado pelo vocábulo "escapismo" . Embora sem relação aparente com o objeto do Novo Romance Histórico Brasileiro, a aquisição de "artefatos de época” revela-se indispensável (pelo menos defendo esta possibilidade) para a compreensão da atual motivação deste tipo de leitor. Observo que a dimensão desta interface é ainda bastante incipiente no campo de estudo das relações entre a

\footnotetext{
${ }^{3}$ Sobre o verbete "subgênero" e também "gênero", ver: REIS, Carlos; LOPES, Ana Cristina. Dicionário de Narratologia. Porto: Almedina, 1987, p. 374-375; PRIETO, Celia Fernandez. História y Novela: Poética de la Novela Histórica. Navarra: EUNSA, 2003, p. 15-27. Aos interessados, em geral, o assunto bem desenvolvido pela professora Dra. Maria de Fátima Marinho, no capítulo "Uma obra em Busca de um Gênero (Considerações sobre o Romance Histórico enquanto gênero)", do livro O gênero literário - Norma e Transgressão, Munchen, Alemanha, Martin Meidenbauer, 2006. Citamos uma frase que elucida tal proposta, mesmo que insatisfatoriamente, a saber: "Perante estas considerações, torna-se claro que, se a definição de romance enquanto gênero estava longe de ser uma classificação baseada em critérios uniformes, o romance histórico (gênero ou subgênero, pouco importa) encontra ainda mais dificuldades em se estabelecer coerentemente." (MARINHO, 2006, p. 140, Grifo nosso)

${ }^{4}$ Ver: SEVCENKO, Nicolau. Literatura como missão. São Paulo: Brasiliense, 1988, p. 21.

${ }^{5}$ Ver: HUYSSEN, Andreas. Seduzidos pela memória. Rio de Janeiro: Aeroplano. Museu de Arte Moderna, 2000.

${ }^{6}$ Tal lacuna exposta foi à produção e apresentação de novos argumentos mais representativos no desenvolvimento deste trabalho. Maiores detalhes, ver: OLIVEIRA, Cristiano Mello de. O Novo Romance Histórico em Travessias: uma leitura dos romances A República dos Bugres e Conspiração Barroca, de Ruy Reis Tapioca. 2016. 432 p. Tese de Doutorado, UFSC, Florianópolis, pp. 383-385.

${ }^{7}$ A repetição de clichês comuns, tais como: "escapismo"; "fuga de uma realidade maçante"; "fuga do cotidiano" em parte, nem sempre explica ou aprofunda a real motivação do público leitor brasileiro pela busca de romances históricos na atualidade.
} 
História e a Literatura. Dito de outro modo: formularei argumentos que defendam a vontade inerente do apelo à "musealização" pela sociedade contemporânea. Atestarei como alguns outros artefatos ligados à memória podem substanciar a possível curiosidade do leitor acerca do passado ou, ao menos, explicar em que medida estes modifica a forma de interação com o passado.

\section{ARTEFATOS DE ÉPOCA E O NOVO ROMANCE HISTÓRICO BRASILEIRO - UMA INTERFACE POSSÍVEL?}

A curiosidade e o consumo por objetos ligados ao tempo passado nos dias atuais ainda está longe de ser encarada como problema resolvido. Quando intitulei esta pesquisa com o uso da expressão "artefatos de época", imaginei que o campo semântico teria alguma relação com alguns produtos relançados - no sentido de abarcar uma espécie de "moda retrô", contudo o resultado não foi exatamente desta forma. E, caso eu conjecturasse, existe uma ambiguidade no próprio campo semântico de tal terminologia cujo conteúdo é ainda mais considerado no campo das relações interdisciplinares. Isso deriva da aplicação do termo tanto no campo da Arqueologia ou da Historiografia. Segundo o dicionário Aurélio (1986, p. 176), a palavra: "artefato", provém do Latim "arte factu, 'feito com arte'; var de artefato", isto é, mantém o seu significado relacionado ao movimento manufatureiro de um determinado objeto de época; também pode ser algo transformado pela ação mecânica do homem. Para fins de correspondência teórica, busco ressignificar esta expressão ao longo do texto - aproximando-a do sentido de remeter voz aos objetos de época - em especial aos produtos recém-lançados pela economia cultural de mercado. ${ }^{8}$

A Indústria Cultural', sobretudo, ganha cada vez mais espaço no universo pessoal e doméstico dos novos tipos de consumidores. É comum identificar alguns adeptos antenados aos meios culturais massivos que remontam lembranças nostálgicas da sua infância ou juventude. Dessa forma, não é fácil se libertar de um passado que sempre foi contagioso em diferentes momentos. "Os resíduos remanescentes de coisas e pensamentos passados representam uma pequena fração da urdidura contemporânea de gerações anteriores.” (LOVENTHAL, 1998, p. 74). Nessa manobra, a memória de muitas gerações atua em duas frentes: a de lembrar situações corriqueiras como os próprios costumes; e a de consumir objetos de décadas anteriores para manter uma espécie de identidade nostálgica. Diversas livrarias e lojas de departamentos

\footnotetext{
${ }^{8}$ Neste caso específico, refiro aos produtos relançados pelas empresas de brinquedos e jogos Grow e Estrela. Ampliaremos o nosso olhar para outros modelos de objetos, mas justificaremos a escolha na redação do próprio texto.

${ }^{9}$ Tomo como acepção sobre o conceito de Indústria Cultural, baseado no Dicionário de Termos Históricos, dos autores Kalina Vanderlei Silva e Maciel Henrique Silva. "Indústria cultural é a produção e a disseminação de produtos culturais para o consumo em massa, ou seja, o consumo de um grande número de pessoas em diferentes lugares, independentemente das particularidades culturais. Tal produção é realizada em geral pelos meios de comunicação e está ligada à atividade industrial propriamente dita. Jornais, revistas periódicas, programas de TV, livros, revistas em quadrinhos, músicas, filmes são exemplos de produtos culturais que passaram a fazer parte da sociedade de consumo surgida nas primeiras décadas do século." (SILVA; SILVA, pp. 225-226).
} 
no Brasil investem neste modelo de público nostálgico, ao completar suas prateleiras com objetos diversos sobre o efeito do passado. Estes funcionam como uma espécie de fetiche de consumo, robustecendo o desejo de satisfazer algo que ficou guardado na lembrança de várias gerações. É comum observar que muitas lojas de brinquedos espalhadas por algumas cidades do território brasileiro apostam no comércio de alguns jogos de tabuleiro - Jogo da Vida, Scotland Yard, Banco Imobiliário; estes fizeram grande sucesso nas décadas de 1980 e 90.

Imagem 1: Ilustrações dos jogos de tabuleiro Banco Imobiliário e Jogo da Vida.

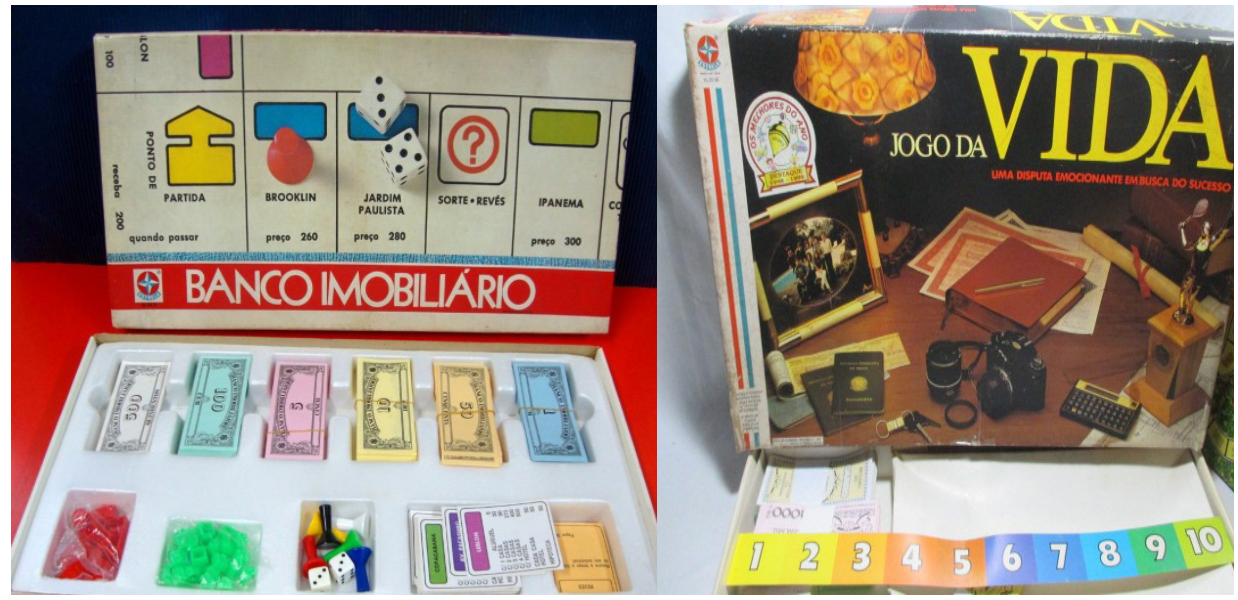

O que está em discussão não é o saber jogar ou simplesmente o tipo de interação o qual estes jogos revelam, mas como tais modelos renovaram a "memória” de várias gerações. Famílias e grupos de amigos passavam horas simulando vidas alheias, uma experiência que, talvez hoje, não se satisfaça como antigamente. Assim como os romances históricos, os jogos de tabuleiro nos provocam a sensação de vivenciar experiências próximas à fantasia e ao conhecimento identitário. Uma espécie de releitura da própria vida perpassa por estes jogos. Neles, o jogador simula técnicas, estratégias para vencer, alimenta angústias e tensões, e sabe que será necessário enfrentar novos desafios até terminar o jogo. Experimentar, basicamente, a magia de nos ocuparmos pela duração do jogo é uma receita que necessita ser devidamente encorajada. É por meio desta fantasia ou "simulação do real", nos termos do teórico Jean Baudrillard, que vigoramos uma espécie de "histeria da produção e da reprodução do real". (BAUDRILLARD, 1981, p. 33).

Basicamente, o segredo do resguardo das relíquias, ${ }^{10}$ dos artefatos de época e dos objetos obsoletos os quais disputam a moda da nostalgia, é voltar ao passado com o olhar contemporâneo.

\footnotetext{
${ }^{10} \mathrm{O}$ autor David Loventhal formula (de forma filosófica) uma boa categoria para o caráter temporal de uma relíquia. “Todas as relíquias, por conseguinte, existem simultaneamente no passado e no presente. O que leva a identificar as coisas como antiquadas ou antigas varia de acordo com o meio ambiente e a história, com o indivíduo e a cultura, com a perspectiva e percepção históricas." (LOVENTHAL, 1998, p. 154).
} 
É como se existisse a obrigação de resgatar uma espécie de "sentido de identidade", conforme nos fala o autor David Loventhal (1998, p. 83). Conjecturo que, no Brasil, não é muito recorrente que este tipo de enigma perpasse o imaginário generalizado de todos os colecionadores, contudo, boa parte ainda mantém esta predileção cultural. Para exemplificar, basta observar o hábito comum de alguns amantes de objetos de época (chamados pelo senso comum de 'colecionadores'); eles se reúnem mutuamente em feiras de antiguidades localizadas nos grandes centros urbanos, como nas cidades de Curitiba (antiquários do Largo da Ordem) e Rio de Janeiro (Feira de antiguidades na rua do Lavradio na Lapa). $O$ gosto pela aquisição de alguns artefatos antigos, ou o hábito de colecionar objetos de época não nasce por acaso - ele atinge pessoas que, geralmente, possuem o desejo mais nostálgico e sentimental. Não é à toa que o imaginário popular de uma espécie de "comercialização em massa da nostalgia" (2000, p. 14), que dia após dia se consolida. Enfim, atestar que o valor oferecido aos artefatos históricos também pode se relacionar pela busca de romances históricos ainda é uma tarefa que precisa se devidamente desvendada.

Para quem já visitou um antiquário ou a denominação criativa Mercado das Pulgas ${ }^{11}, \mathrm{o}$ ideal é encontrar "artefatos de época" os quais podem fartamente complementar o mobiliário de uma casa que possua decoração clássica ou antiga. Obviamente que isso não é uma regra de gosto, pois existem também consumidores que mesclam o ambiente doméstico com peças novas e antigas. Como muitos sabem, a comercialização de produtos antigos é o carro chefe deste modelo de negócio, que por ora cresce em números nos centros urbanos. Muitos críticos ainda afirmam que existe uma preocupação com a sustentabilidade ligada ao consumo mais consciente, ou seja, ao lado ecológico. Voltar à cena do passado ou, simplesmente, remeter luz às experiências remotas, como anuncia o site deste antiquário, parece que virou clichê entre os mais entendidos do assunto. É possível calcular que gerações de pessoas ainda costumam frequentar este local para buscarem novos arranjos na decoração de residências ou simplesmente do próprio ambiente de trabalho. Portanto, é bastante nítido que quem busca decorar uma residência com móveis de madeira de lei (como é classificada a madeira nobre), quadros antigos que remontam a uma determinada época, apetrechos domésticos diferenciados, utensílios nostálgicos, acabam sempre intensificando o tom de uma determinada época.

Não somente jogos de tabuleiro têm feito às ideias da turma mais confiante ao efeito do passado, mas também incontáveis relançamentos de brinquedos (dos quais muitos fizeram sucesso na década de 1980) ${ }^{12}$ que conseguem satisfazer um nicho cada vez maior de consumidores ligados a este apego. A ideia não é ampliar o leque, mas apenas situar como os horizontes desta

\footnotetext{
${ }^{11}$ A denominação Mercado das Pulgas é o nome fantasia de um antiquário da cidade de Curitiba-PR. Segundo informações do site, a loja foi inaugurada em 1988. O principal argumento de marketing do negócio é o não descarte de objetos e artefatos antigos, pois esses podem ser aproveitados para diversos fins.

${ }^{12}$ Informo que não tive acesso aos dados dos produtos que fizeram sucesso na década de 1980 e que, atualmente, estão sendo relançados, contudo a frase: "Celebre os 80 anos da Estrela com a versão retrô do tradicional Banco Imobiliário.", pinçada no site da empresa Estrela, ilustra e justifica o nosso argumento acima.
} 
pesquisa podem se tornar amplo. Alguns artefatos de época, se assim posso dizer, encabeçam a lista dos mais adquiridos por grupos de adultos e jovens (que supostamente acompanham os gostos dos pais). Se ousássemos a simples visita a uma loja mais personalizada, ou folheássemos um catálogo de lançamentos de produtos, encontraremos diversos brinquedos que remontam a esta época. Houve, na década de 1980, um grupo seleto de pessoas que desfrutaram de jogos interativos eletrônicos, os quais testavam a memória do jogador. Muitos desses tornaram-se fenômenos massivos no meio mercadológico brasileiro. Refiro-me ao brinquedo eletrônico Genius, fabricado pela empresa brasileira Estrela testava os limites da memória sonora - por meio de sons diversos - e da memória visual - por meio de diversas cores.

Imagem 2: Brinquedo eletrônico Genius - Empresa brasileira Estrela ${ }^{\circledR}$.

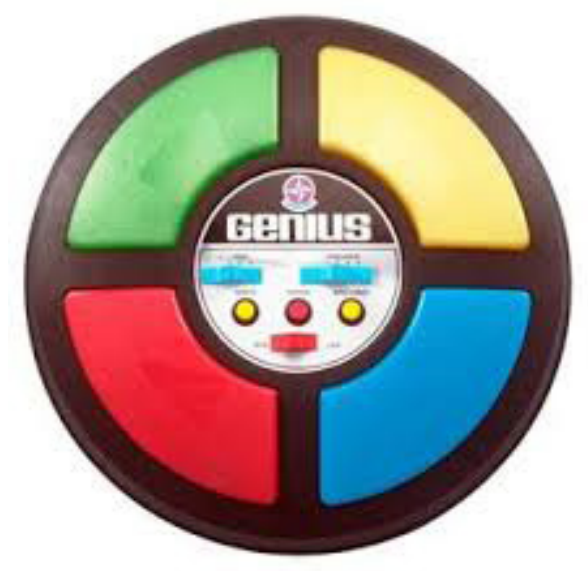

Investir no passado não é somente tarefa da indústria dos brinquedos ou jogos, por outro lado, também cresce a quantidade de séries históricas - como é o caso mais recente do grupo norte-americano da Plataforma Netflix. Obviamente que adentrarei numa nova seara de público internacional, que ao mesmo tempo se mostra fascinado pela História dos acontecimentos globais. A efervescência pela memória dos fatos remotos atravessa gerações de espectadores assíduos para conhecer a História de algumas nações - somando vários aspectos a favor. Algumas séries são montadas a partir da leitura de romances históricos - adaptando densos enredos literários para roteiros nem sempre densos de dramaticidade. ${ }^{13}$ Para citar algumas séries: Troia: a queda de uma cidade (2018), Spartacus (2013), Império Romano (2018), A catedral do mar (2017), dentre outras que alimentam novos gostos de predileção. Nestas séries é possível verificar vários depoimentos históricos no desenrolar da trama (funcionando como um documentário, exigindo uma familiaridade com os acontecimentos históricos por parte

\footnotetext{
${ }^{13}$ Para justificar esta afirmação, me apoio na reflexão de Robert Stam, quando diz: "E a adaptação nunca é meramente uma cópia: ambos, fonte e adaptação, estão enredados em múltiplos repertórios, gêneros e intertextualidades”. (STAM, 2008, p. 25).
} 
do espectador). Nos produtos mencionados, pode-se notar como são exploradas técnicas historiográficas fornecidas por muitos escritores e historiadores especialistas.

A esta altura, poderia surgir daí uma ampla questão: que tipo de memória e como este tema tem fascinado a mentalidade de alguns pesquisadores? A crítica argentina Beatriz Sarlo arrisca uma resposta:

Nunca como hoje a memória foi um tema tão espetacularmente social. E não se trata apenas da memória dos crimes cometidos pela ditadura, situação na qual a lembrança social preserva o desejo de justiça. Tratase, também, da recuperação das memórias culturais, da construção de identidades perdidas ou imaginadas, da narração de versões e leituras do passado. (SARLO, 2005, p. 95-96).

Por um viés paralelo, a releitura de fatos e acontecimentos históricos por meio do subgênero literário chamado romance histórico é cada vez mais presente em várias estantes de diversas livrarias espalhadas pela Europa e no Brasil. Não por acaso, diversos modelos memorialísticos literários são trabalhados por autores brasileiros - perfazendo uma releitura de alguma identidade esquecida, como foi o caso do romance-diário Em Liberdade, lançado em 1981, do escritor Silviano Santiago. É cabível dizer que o romance de Silviano ajudou a reerguer notoriamente o conceito de público aficionado por leitura deste modelo de gênero. $O$ enredo reinventa (com forte investigação histórica) a vida do escritor Graciliano Ramos após sua saída do presídio de Ilha Grande no Rio de Janeiro. Neste romance histórico, se assim preferimos, o protagonista Graciliano é testemunhado pela sua própria escrita; resgatando pistas memorialísticas de uma vida cheia de percalços intelectuais. À maneira da escrita de Graciliano, Santiago reconstituiu o estilo do autor, recompondo o encontro do autor de Vidas Secas com diversas figuras intelectuais na cidade do Rio de Janeiro. Uma questão abrangente urge: como verificar a possível interface entre a busca de artefatos de época com a motivação do público leitor por romances históricos? A resposta exige certo raciocínio para não exagerar na dose de amplitude que o tema pode suscitar.

Acredito que é por meio deste contexto do consumo de artefatos de época esboçados acima - que o Novo Romance Histórico Brasileiro (um retroalimentando o outro) também busca o seu espaço no gosto comum de alguns apreciadores do subgênero. Desse modo, a suposta lógica da motivação do leitor pela busca de romances históricos parece se confundir com algumas dessas circunstâncias apontadas por Sarlo (salvaguardando algumas diferenças geográficas e culturais óbvias entre o Brasil e a Argentina, as ideias da autora são alusivas), pois: "trata-se de uma cultura da velocidade e da nostalgia, do esquecimento e da comemoração de aniversários." (SARLO, 2005, p. 96). Conforme já comentei, ler este modelo literário, se assim posso dizer, é compreender de forma mais dramatizada e lúdica como o passado foi operado e sistematizado por alguns historiadores, assim como os documentos deram voz imediata 
ou não aos fatos. As representações de fatos referenciais figurados em determinados enredos históricos também viram potenciais para serem transformados em acessórios: bonecos, cenários, camisetas, canecas, tudo vira mercadoria. Basta atestar como a saga histórica do escritor norte-americano Dan Brown (Código da Vinci, Inferno, Fortaleza Digital, Anjos e demônios, Origem) foi expandida para diversas formas de produtos.

Se a febre das séries tem provocado uma forte popularização dos meios midiáticos de transmissão historiográfica via cinema, conforme apontei acima, é comum que a febre da monumentalização e o apreço excessivo pela memória de vários espaços públicos, também sejam alvos de muitas investigações por parte de alguns pesquisadores. Na prática, existe uma espécie de "fome de realidade", conforme destaca o autor Karl Eric Schollhammer (2013, p. 155) visando diagnosticar um apreço excessivo pelo real. A esse respeito, o paralelo mais breve possível é saber que o romance histórico brasileiro é altamente tributário do romance realista do século XIX. São angústias de interesse que perpassam o imaginário daquelas pessoas mais preocupadas pelo resgate da identidade nacional ou da simples preservação da memória. Longe do território brasileiro, sítios arqueológicos urbanos e locais ociosos (que antes acolhiam instituições ou prédios públicos) ganham espaço no conceito arquitetônico das cidades modernas, conforme aponta o alemão Andreas Huyssen (2000, p. 14). Em especial as europeias Londres, Paris, Lisboa, Madri, Berlim são capitais que se preocupam cada vez mais por uma lógica de preservação museológica à qual atenda às necessidades identitárias de cada projeto de nação. Linhas adiante, citando o crítico alemão Hermann Lubbe, o autor Andreas Huyssen disserta: "O diagnóstico de Lubbe pressupõe um historicismo expansivo de nossa cultura contemporânea, e segundo ele, jamais uma cultura foi tão obcecada pelo passado como a nossa." (HUYSSEN, 2000, p. 239).

Saindo da atmosfera da arquitetura histórica de algumas cidades, defendida por Huyssen, temos a efervescência pela leitura dos romances históricos. A autora Letícia Malard, docente universitária da UFMG, defende o gosto do público leitor por romances históricos, partindo para uma análise mais utilitarista e pragmática. Ou seja, a utilidade que resguarda o caráter informativo historicista o qual muitos romances históricos possuem e, às vezes, nem sempre exploram. Se fosse observado por este olhar, certamente afirmaria que o Romance Histórico possui uma vocação para instrumentalizar os leitores acerca dos fatos da nação e, obviamente, que eles dinamizam e dramatizam a forma didática trabalhada pelos docentes citados. De acordo com a autora: "A preferência por esse tipo de literatura poderia corresponder à rejeição de narrativas inventadas do nada (ainda que se tenha como certo que toda narrativa se constitui em transformação das que a antecederam), ou seja: os leitores comuns estariam perdendo o interesse por ficções originárias do imaginário/imaginação de um sujeito individualizado.”. (MALARD, 1996, p. 144).

A esta altura, é importante que tratemos também da forma didática e pedagógica dos romances históricos escritos por autores oriundos de alguns países vizinhos ao Brasil. É a 
partir daí que o passado idealizado e cristalizado se reinventa, partindo para uma leitura desconstrucionista e crítica dos fatos e acontecimentos pretéritos, conforme nos alerta o autor Gilmei Francisco Fleck. Durante a leitura do ensaio de Fleck observei que o panorama histórico, geográfico e cultural oferecido pelo autor é rico e merece muita leitura e atenção aos dados fornecidos pela História oficial. Para fundamentar o seu argumento, Fleck defende que o romance histórico Xicoténcatl, publicado por um autor anônimo, em 1826, teve a função de alertar o leitor para a tirania exercida por alguns conquistadores ao dominar barbaramente a nação mexicana. De sobra para fins de argumentação, como "exercício de escrita anticanônica", o autor também cita os romances El reino de este mundo (1949), de Alejo Carpentier e Yo el Supremo (1974), de Augusto Roa Bastos. Ampliando os horizontes de raciocínio, dentro do contexto latino-americano, em especial aos romances históricos cujo conteúdo abastece o enredo de colonização de algumas metrópoles da América Latina, o pesquisador citado acredita que a leitura de romances históricos possibilita "descolonizar a mente do leitor, tomada de imagens consagradas e heroificadas de sujeitos europeus”, (FLECK, 2017, p. 126-127) ampliando, dessa forma, "a possibilidade de reterritorializar o espaço imaginário dos colonizados".

Concordo que preencher o espaço do imaginário do colonizado, conforme nos alerta Fleck pode ser um diagnóstico muito importante para um leitor mais familiarizado com os acontecimentos de época, caso contrário este também terá dificuldades de entendimento e interpretação, gerando uma possível desistência da leitura. É por este motivo e outros que muitos inquéritos sondam possibilidades de público leitor antes mesmo da publicação de alguns romances. Para o escritor português Nuno Gomes Garcia, autor de vários romances históricos, algumas razões essenciais são importantes para motivar um leitor a adquirir este modelo literário. Guardada as devidas ressalvas, seu raciocínio também pode ser diretamente alusivo ao contexto cultural brasileiro e consequentemente latino-americano. Embora sua resposta à entrevista não seja tão acadêmica, é importante registrar que a reflexão de alguns escritores também fortalece o critério de recepção e a motivação desses leitores na sociedade atual.

Em uma matéria intitulada "O romance histórico", publicada no Jornal de Letras, em agosto de 2015, ao ser questionado sobre o interesse do público leitor, o autor diz: "Existe, sim, um natural fascínio do leitor pelo romance histórico. A História ensina-nos que somos e por que somos e como somos. Hoje, esse fascínio creio ter sido potencializado por uma certa uniformização da cultura, fruto desta globalização mercantil que vivemos. As nossas sociedades modernas são artificialmente homogêneas, o que do meu ponto de vista é negativo. Por isso, os leitores, em tempos de crise, tanto socioeconômica como até de identidade, procuram a História e o romance histórico como algo que os fundamente, os situe, que os diferencia a si à cultura num contexto global de quase absoluta estandardização." (GARCIA, 2015, p. 7).

O que parece resumir a reflexão acima é a inerente vontade do público leitor por uma forma de conhecimento histórico não uniformizado à realidade da nação. Ou seja, a leitura de 
romances históricos parte para compreender novos vieses historiográficos narrados, longe de uma narrativa hegemônica. Ainda acerca da motivação pela leitura de narrativas históricas, algumas respostas mais abrangentes ganham a cena e o palco. Sem cair no recurso fácil da busca constante de conhecer as nações exóticas ou fugir de um presente estarrecedor, é a partir daí que se identifica o potencial do público leitor geral, seja ele desconhecedor dos fatos, seja ele amante da História de época. Quer seja a resposta generalista ou não, é possível ainda encontrar uma possível mácula neste assunto: o risco inerente de afirmar que a motivação de leitura por romances históricos ocorre pela chamada crise vigente da identidade na era da pós-modernidade ${ }^{14}$. Em entrevista, realizada no fim da pesquisa citada na introdução, a respeito da motivação do público leitor por romances históricos, o romancista baiano Ruy Reis Tapioca responde: "São cíclicos (vêm e voltam, recrudescem e desaparecem) em conformidade com a ocorrência de crises, guerras e conflitos no mundo. Já reparou que os americanos não mais escrevem (ou mesmo fazem filmes) sobre o western selvagem? Ou mesmo sobre fatos e conflitos da $2^{a}$ Guerra Mundial? Creio ser inevitável que as próximas aventuras de James Bond tenham terroristas do Estado Islâmico ou da Al-Qaeda como vilóes. Assim caminha a humanidade". (TAPIOCA, 2016, p. 434).

Por mais que o depoimento generalista de Ruy Tapioca seja desafiador e problemático, o certo é que ainda carecemos de um real diagnóstico que consiga formular gráficos e números acerca da motivação do leitor comum por acontecimentos históricos. Poucos estudos revelam, em graus estatísticos, o somatório desses leitores. Do ponto de vista sobre o acesso e a busca pelos livros históricos, por parte das pessoas comuns, o historiador Peter Burke afirma:

Parece que existe de fato um "boom" da história, no sentido de que uns poucos historiadores, alguns deles historiadores acadêmicos sérios, atraem agora um público amplo. Não explico isso como nostalgia, se com isso se quer dizer uma preferência por viver no passado. Uma explicação poderia ser "turismo no tempo", um gosto pelo exótico, por viagens sem sair da poltrona a períodos remotos como se fossem lugares remotos. Concordo com você que muitas pessoas recorrem à história, sobretudo a sua própria história, para buscar suas raízes, e elas precisam disso mais do que nunca por causa da rapidez das mudanças sociais. (BURKE, 1994, s/p).

Por um viés semelhante, é instigante anunciar, em termos mundiais, que a narrativa histórica tornou-se um subgênero literário afeito a grupos específicos de leitura e discussão dos romances. Assim, o estimulante desse exercício é pensar o subgênero como artefato que gera discussão, debates e testemunhos de leituras perante um público leitor cada vez mais fiel. No caso brasileiro, há leitores formados pelo mesmo gosto em comum: a paixão por

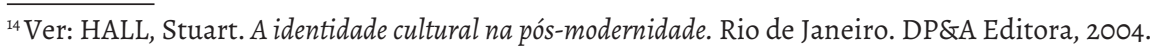


romances históricos e seus autores, de modo a descortinar a troca de experiências de leitura, assim como promover encontros que proporcionam unir essa seletividade tão afeita ao subgênero. É a partir daí que a informatização dos gostos literários e formação de opiniões pelas redes sociais são úteis para conjugar ideias tão comuns e distantes, revelando que no Brasil a produção de romances históricos é autossuficiente. Na rede social Facebook, o grupo mantém uma comunidade aberta denominada "Romance Histórico Brasil", abrindo o convite para novos membros e usuários.

Imagem 3: página inicial da comunidade "Romance Histórico Brasil”, administrada por Vânia Nunes

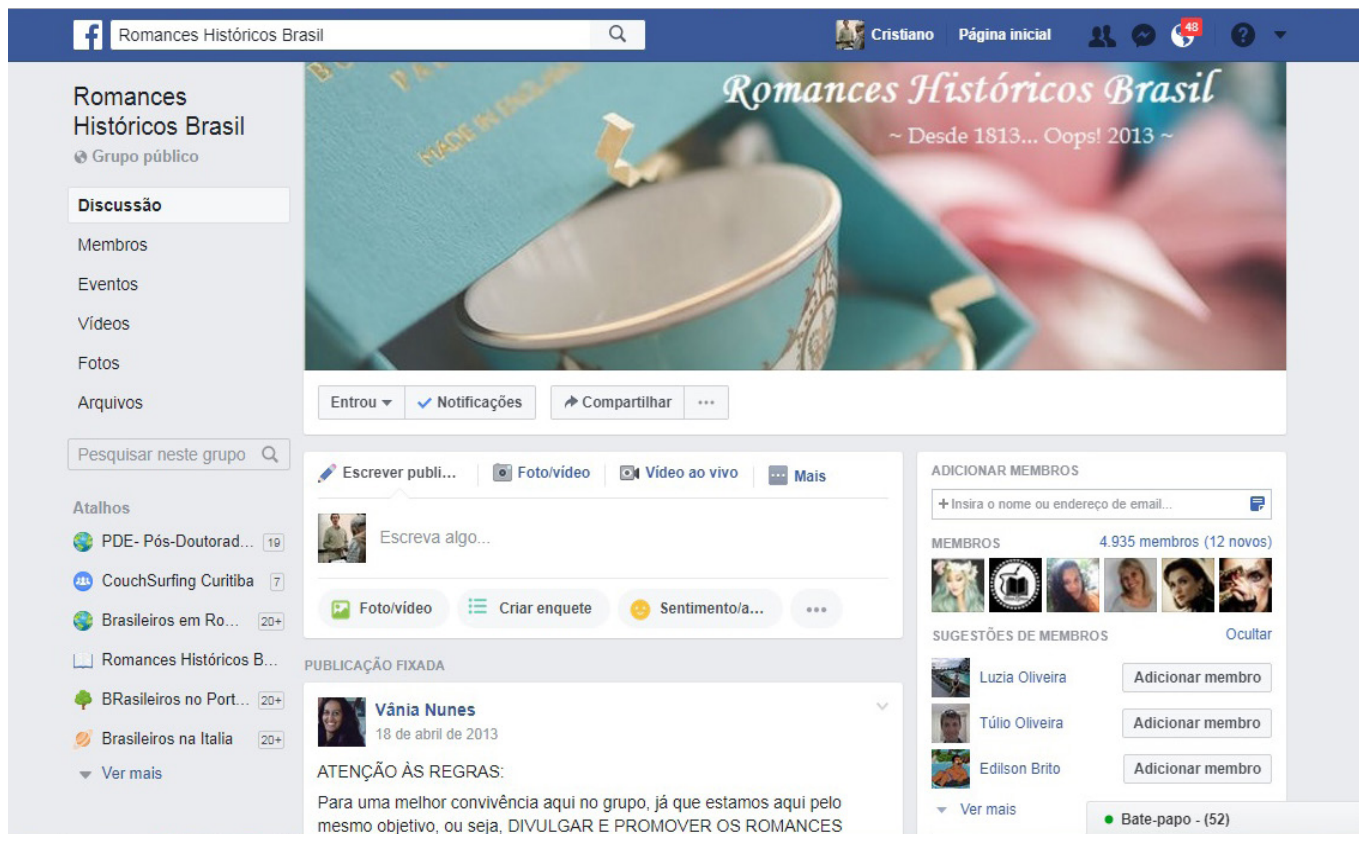

Ademais, pode-se presumir que esse tipo de organização também favorece uma regularidade de leituras de romances históricos publicados no Brasil, seja pela publicidade dessas obras literárias nas mídias sociais, seja pelos debates promovidos acerca do tema. Não foi objetivo de essa pesquisa examinar as postagens realizadas pelos participantes do grupo, que por si só, seriam objeto de estudo de várias investigações acerca do interesse pelo subgênero. Imiscuindo-se da discussão acadêmica acerca das formulações teóricas do subgênero, ou mesmo das formulações teóricas básicas que regem o conceito de romance histórico, o grupo se satisfaz pelo gosto e prazer desinteressado da leitura de muitos romances históricos. Conforme a minha última visita à comunidade estabelecida, constatei o número de 1500 participantes registrados ${ }^{15}$. A filiação dos usuários é abrangente e requer, por parte do pesquisador, um

\footnotetext{
${ }^{15}$ Romances Históricos Brasil. Administradora Vânia Nunes. Facebook. Disponível em: https://www.facebook.com/ groups/RomancesHistoricosBrasil/?fref=tsA. Acesso em: 20-10-2014.
} 
olhar meticuloso. Nos devidos termos, atestei que a variedade de interessados formados por profissões distintas enriquece bastante o convívio desses leitores aficionados pelo subgênero. Dentro do meu raciocínio, o único problema é que a página oficial da comunidade não chega a estimar um número aproximado de leitores interessado ${ }^{16}$. De igual modo, a administradora da página, Vânia Nunes, logo no cabeçalho das postagens, alerta aos primeiros membros sobre as normas e o regulamento. Através de um elenco de cinco regras básicas ${ }^{17}$, Vânia regula a parte de convivência mais harmônica para o grupo. Ao que tudo indica, o grupo explora a questão dos lançamentos mais diversificados de romances históricos em vários idiomas e traduções. Em suma, esse diagnóstico torna-se válido pela importância dedicada ao subgênero do romance histórico no Brasil, evidenciando predileções que nem sempre dominavam os catálogos das livrarias e das bibliotecas.

\section{A MOTIVAÇÃO DO PÚBLICO LEITOR POR ROMANCES HISTÓRICOS NA RECÉM-ATUALIDADE}

Ao que tudo indica e conforme estamos argumentando, a motivação parece ser promovida pela ordem de características inerentes a uma mesma interface: o lado nostálgico e o despertar por parte do leitor pelos acontecimentos pretéritos. Uma simples caminhada pelas bancas ${ }^{18}$ e livrarias fará com que o pesquisador perceba a quantidade de revistas de história - Revista de História da Biblioteca Nacional, Leituras da História, Revista História Catarina, entre outras -, presas às prateleiras ${ }^{19}$. Imperceptíveis à primeira vista, esses modelos de publicação alavancaram o interesse geral pela História por parte do público leitor brasileiro. Sem investigar a fundo, suponho que o consumo por esse tipo de leitura manteve um equilíbrio sustentável durante os últimos anos. Diga-se de passagem, são publicações que acolhem diversos tipos de público e ao mesmo tempo conseguem divulgar matérias indispensáveis ao entendimento da nação. Por trás desse sentimento nostálgico e passadista, por parte dos leitores, a proliferação de abordagens acerca dos episódios da História brasileira cresceu exponencialmente, tornando-se algo rentável para as principais editoras do país, ampliando novas páginas e capítulos, fora daquilo que os meios acadêmicos pregavam por meio das teses e dissertações, promovendo um espaço promissor na articulação entre "passado e presente".

\footnotetext{
${ }^{16}$ Interessante notar que algumas questões a esse respeito renderiam uma excelente discussão acadêmica, assim como vários desdobramentos. A saber: qual seria o perfil de leitores de romances históricos? O que esse público gosta de ler? Preferem ler em casa ou nas instituições, bibliotecas etc? Estão lendo para adquirir formação ou simplesmente entretenimento?

${ }^{17}$ Sobre as regras e o estatuto da comunidade estabelecida no Facebook: ver página da comunidade indicada no texto.

${ }^{18}$ Curioso identificar que muitos romances históricos são vendidos em bancas de jornal espalhadas pelas cidades do país. Essa situação mereceria um estudo à parte. Conforme nossa breve consulta destacam-se os romances históricos do autor Aydano Roriz. São eles: RORIZ, Aydano. O Desejado. São Paulo: Ediouro, 2002; O livro dos hereges. Rio de Janeiro: Ediouro, 2004; Nova Lusitânia. São Paulo: Ed. Europa, 2008; Van Dorth. Rio de Janeiro: Ediouro, 2006.

${ }^{19}$ Interessante afirmar que muitas dessas revistas de divulgação histórica ficam devendo matérias que abordem romances históricos ou mesmo a relação entre história e literatura.
} 
Imagem 4: Capas ilustrativas das revistas Leituras da História e História da Biblioteca Nacional.
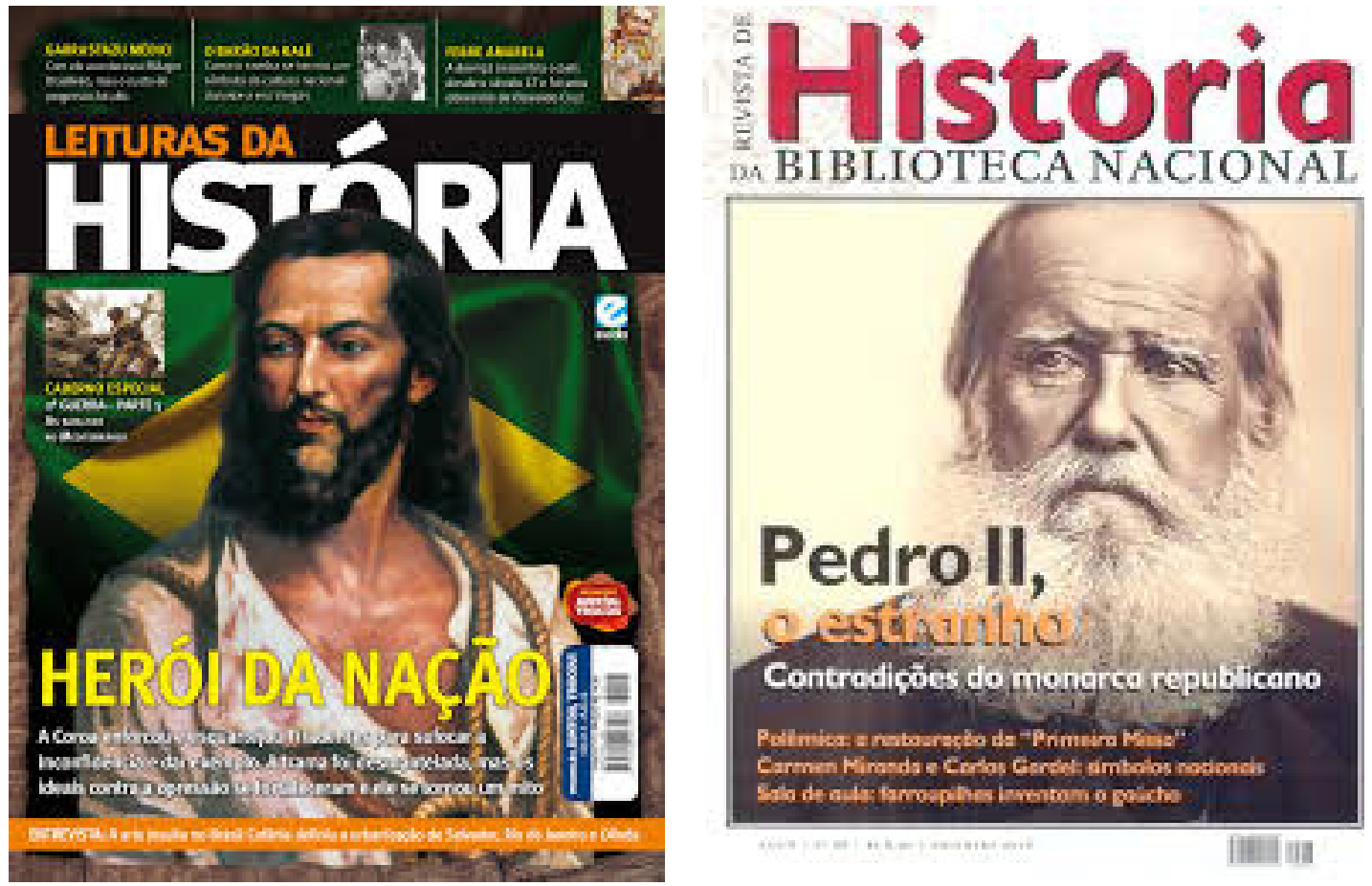

É bastante consensual afirmar que a busca por essas revistas históricas ou por romances históricos despertam o interesse pelo passado, mas não muito esclarecedor em si. Em retrospecto, o autor Antônio Esteves, ao observar o fenômeno, reflete: "as livrarias expõem nos lugares mais visíveis uma grande quantidade de best sellers que tratam de fatos ou personagens históricos". (ESTEVES, 2008, p. 05). Em outras palavras, esta tipologia de interesse sequer pode ser encarada como um modelo cultural a "portas fechadas" pois, na atualidade, virou formato literário de interesse de muitos leitores. Nessa esteira apontada por Esteves, muitas livrarias espalhadas por vários países - Colômbia, Argentina, Costa Rica, Portugal, Espanha, conforme nossa visita -, ao contrário do Brasil, chegam a criar divisões específicas (juntamente a seus autores mais relevantes) para acomodar os romances de natureza histórica $^{20}$. É bem verdade que isso facilita a visualização desse subgênero, caso o Brasil também

\footnotetext{
${ }^{20}$ Durante dois congressos realizados nas cidades de Calli (JALLA-Jornada Andina de Literatura Latino-americana - 30 de julio a 03 de agosto de 2012), na Colômbia, e Mendoza (I Congreso Internacional Nuevos Horizontes de Iberoamérica $-6,7$ e 8 de novembro de 2013), na Argentina resolvi visitar algumas livrarias e comprovar que as divisões sistemáticas de romances de natureza histórica acabam ajudando o leitor que deseja visualizar melhor tais obras. Ao discriminar autores de romances históricos de outros que não sejam as livrarias facilitam a vida do público leitor. Em Costa Rica, Portugal e Espanha, países recentemente visitados, as divisões também são sistemáticas nesse sentido. Por contraste, ainda no Brasil não temos uma divisão mais específica, dificultando, em maior grau, a localização do livro, assim como o seu manuseio. A esse respeito, uma reflexão relacionada ao contexto espanhol das livrarias é importante a ser compilada. Nas palavras do autor Santos Sanz Villanueva: "A más há ido y a las pruebas me remito. Hoy es normal que los espacios libreros grandes tengan su generosa sección dedicada en exclusiva a este tipo de novelas. Alguna editorial se
} 
adotasse, funcionando como uma amostra sistematizada, corroborando para a seleção, manuseio e compra do livro pelo leitor.

Imagem 5: foto tirada pelo autor Cristiano Mello de Oliveira. Livraria Casa Del Libro, na cidade de Madrid. Espanha. Data 25/05/2015.

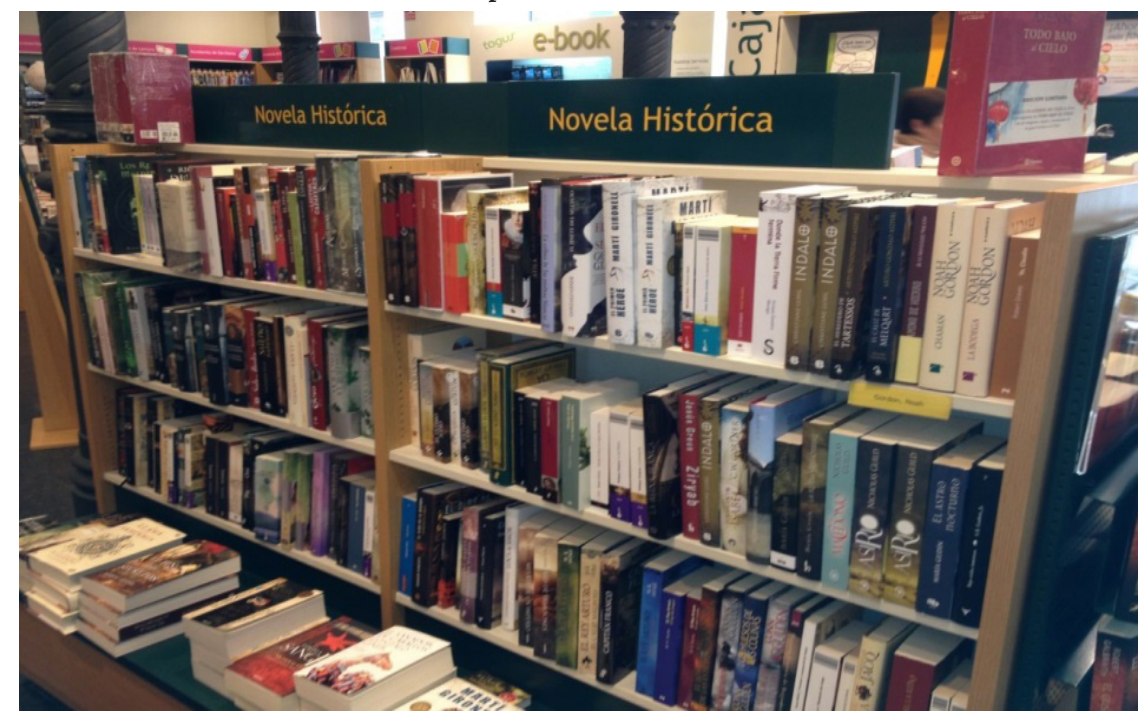

Dentro desse raciocínio, a mercantilização da memória e do passado, conforme nos fala novamente o crítico Andreas Huyssen (2000, p. 09), amplia os horizontes da especulação histórica sobre os principais eventos históricos de muitas nações. Somando a esses fatores, os jogos eletrônicos para diversas plataformas também têm mantido o verdadeiro esforço de formular enredos para games que possam instruir ou ao menos incentivar o jogador interessado sobre o aprendizado de vários acontecimentos históricos ${ }^{21}$. Portanto, revistas de conteúdo histórico, sites com informações históricas, jogos eletrônicos com base em enredos históricos, têm corroborado para o aprendizado de História nos últimos anos e, consequentemente, instigando muitos alunos a buscarem outras fontes e referências.

A expressão "emergência da memória” (HUYSSEN, p. 09), usada pelo crítico alemão Andreas Huyssen, no ensaio Seduzidos pela memória (2000), foi pensada pelo autor para

mantiene prácticamente de fabricar este produto y todas le hacen un bueno hueco com la intención de sanear la cuenta de resultados. El modesto premio específico para este género que luego se anota há sido relevado por outro sino vários galardones, de certo fuste y con ayudas oficiales.”. (VILLANUEVA, 2006, p. 220).

${ }^{21}$ Conforme matéria intitulada "Aventuras virtuais no passado-games abordam eras reais, despertando interesse, mas muitas vezes distorcem os fatos", publicada no Jornal O Globo, no dia 17de janeiro de 2015, escrita pelo jornalista Thiago Jansen (Thiago.jansen@oglobo.com.br). Neste, o autor discorre sobre os testemunhos históricos que são abordados em vários jogos, alertando, com os depoimentos de especialistas, o risco de muitos games distorcerem os fatos históricos. "Como milhares de jogadores de videogames ao redor do mundo já perceberam, não é preciso apenas imaginar: cada vez mais jogos eletrônicos vêm adotando a História como base de seus enredos. Se por um lado, eles podem ajudar a criar interesse no aprendizado da matéria, por outro as liberdades históricas tomadas na criação dos jogos suscitam alertas de especialistas." (JANSEN, 2015, p. 25). 
caracterizar uma das preocupações culturais na sociedade ocidental, ou seja, a busca incansável do registro e do armazenamento compulsório ${ }^{22}$. O cerne da sua discussão é a análise dos mecanismos que a sociedade global adquiriu como estratégia de reter o máximo de informações, visando jamais perdê-las. É bem claro que o fulcro dual desses dois fatores motiva muitas pessoas a formularem um passado sacralizado em relação ao presente. A meu ver, o único problema é que por trás desse entendimento há uma real necessidade de interrogarmos sobre os objetivos dessa exausta vontade de armazenar múltiplas coisas sem a devida consciência crítica. Desdobrando as reflexões de Huyssen, ele nos ajuda a compreender um dos fenômenos globais que observamos a cada dia: a tarefa incansável e frenética das pessoas registrarem obsessivamente os diversos momentos por meio de diferentes plataformas de armazenamento ${ }^{23}$.

Em evento intitulado "II Ciclo de Palestras: Os Mestres da Narrativa Histórica Brasileira", idealizado por mim e pela minha orientadora Dra. Rosana Cássia Kamita, apresentamos alguns resultados importantes acerca da motivação do público leitor pelo Novo Romance Histórico brasileiro. O ciclo ocorreu na Biblioteca Universitária da Universidade Federal de Santa Catarina. Naquele período (agosto a dezembro de 2014) fiz a curadoria que contou com 10 palestrantes convidados para abordarem temas relacionados aos romances históricos publicados nas cinco regiões do Brasil. As questões centrais que permitiram essa reconstrução foram precisamente a noção de motivação mais ou menos abrangente e mais ou menos refletida, e a forma como se avoluma este interesse. Na ocasião, também foi aplicado um questionário de pesquisa, o qual verificava o diagnóstico da motivação do público leitor acerca de romances históricos. As respostas dadas pelos entrevistados (se analisadas em

\footnotetext{
${ }^{22} \mathrm{~A}$ intensa busca pela memória não para por ai, mesmo o contexto sendo europeu ou norteamericano, Huyssen cria um verdadeiro diagnóstico sobre tal questão. Segundo o autor: "Desde a década e 1970, pode-se observar, na Europa e nos Estados Unidos, a restauração historicizante de velhos centros urbanos, cidades-museus e paisagens inteiras, empreendimentos patrimoniais e heranças nacionais, a onda da nova arquitetura de museus (que não mostra sinais de esgotamento), o boom das modas retrô e dos utensílios reprô, a comercialização em massa da nostalgia, a obsessiva aumusealização através da câmera de vídeo, a literatura memorialística e confessional, o crescimento dos romances autobiográficos e históricos pós-modernos (com as suas difíceis negociações entre fato e ficção), a difusão das práticas memorialísticas nas artes visuais, geralmente usando a fotografia como suporte, e o aumento do número de documentários na televisão, incluindo, nos Estados Unidos, um canal totalmente voltado para História: o history channel." (HUYSSEN, 2000 , p. 14). Por outro lado, analisando a moda retrô, a onda de colecionar objetos antigos e a busca por artefatos obsoletos por várias pessoas na atualidade, complementando o estudo de Huyssen, a pesquisadora Beatriz Sarlo tece algumas considerações que soam alusivamente importantes para essa espécie de reavaliação do passado pela moda. De acordo com ela, a popularização de artefatos de época atinge muitos jovens na diferentes camadas. Nas suas palavras: "Como a roupa hippie dos anos 1960, a fantasia de discoteca não exclui a combinação de diferentes temporalidades e origens: retrô punk, retrô romântico, retrô cabaré, retrô folk, retrô militar, retrô Titanes en el Ring, retrô rasta, gigolô, femme fatale, demi-mondaine, prostituta de Almodóvar." (SARLO, 2013, p. 46).

${ }^{23}$ Interessante frisar que anterior às fórmulas reflexivas utilizadas por Andreas Huyssen, o crítico Roland Barthes, no seu ensaio "O rumor da língua", também já previa a obsessão do público contemporâneo pelo excesso de registro à memória. Provavelmente Huyssen tenha lido Barthes. Nas palavras de Barthes: "Há um gosto de toda a nossa civilização pelo efeito de real, atestado pelo desenvolvimento de gêneros específicos como o romance realista, o diário íntimo, a literatura de documento, o fait divers, o museu histórico, a exposição de objetos antigos, e principalmente o desenvolvimento da fotografia, cujo único traço pertinente (comparada ao desenho) é precisamente significar que o evento representado realmente se deu." (BARTHES, 2004, p. 178-179).
} 
profundidade) permitem tirar algumas conclusões, ainda que parciais. No fim de cada palestra, o monitor responsável distribuía os questionários formulados para os participantes responderem algumas questões, a saber: quais as motivações do público leitor contemporâneo pela leitura de romances históricos? As respostas estabelecidas pelos participantes foram: conhecer e ampliar os horizontes da História lida nos livros didáticos. A segunda questão: quando você compra um romance histórico, o que você observa durante o ato da compra? A resposta: se os acontecimentos históricos são relevantes para o seu conhecimento. De um modo geral e mesmo que panorâmico pelo teor das perguntas e do perfil do público participante os dados revelam que a busca de romances históricos pelo público leitor ocorre pela vontade de conhecimento histórico, fugindo da literatura como mera ficção ou simples entretenimento, como apontara Letícia Malard acima. Doutro lado, parece haver certa ansiedade de encontrar subsídios que aprofundem questões identitárias ou ao menos que revelem fatos embrionários da nação.

Imagem 6: Foto do cartaz do evento: II Ciclo de Palestras: Os Mestres da Narrativa Histórica Brasileira. Florianópolis: BU-UFSC, Agosto/Dezembro, 2014.

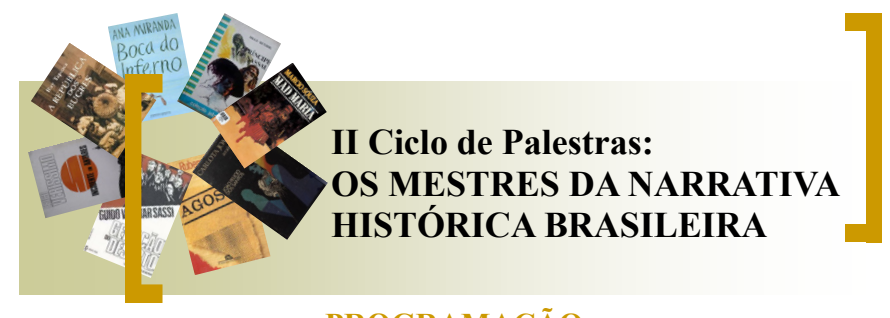

\section{PROGRAMAÇÃO}

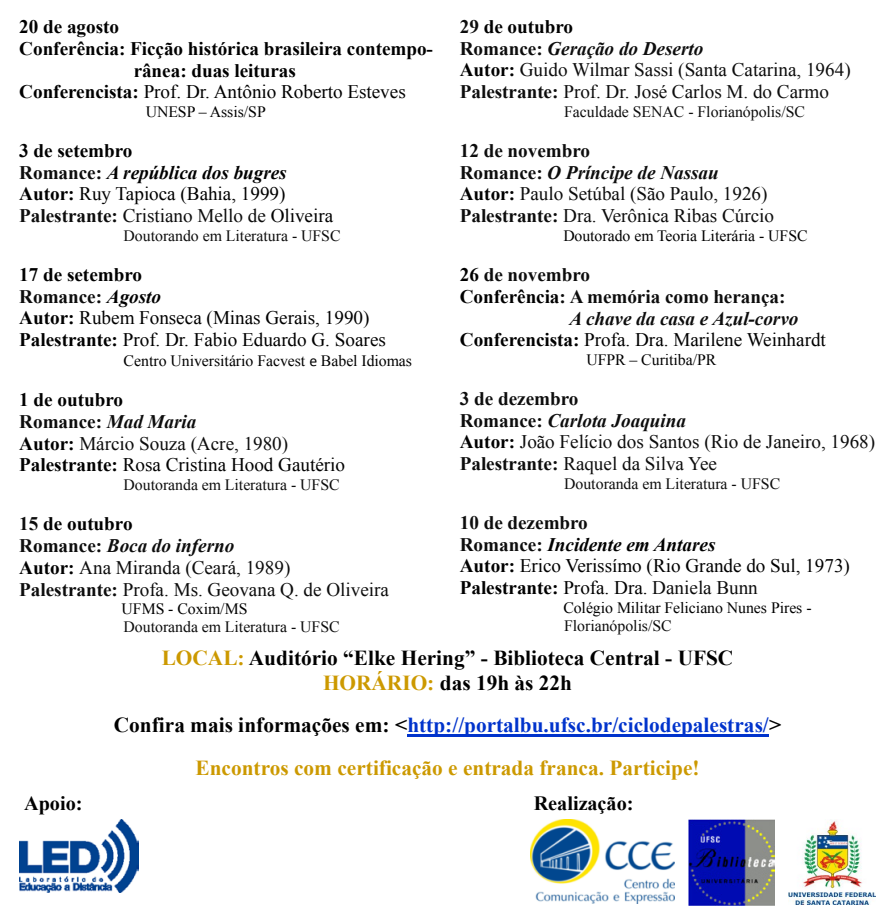


Da razão objetiva acerca do conteúdo registrado por alguns romances históricos para o grande número de leitores interessados nos dias atuais, é plausível identificar um crescimento exponencial. Dentro deste raciocínio, é um percurso investigativo promissor diagnosticar a quantidade de leitores ligados ao subgênero, sobretudo, os aspectos que movem esse interesse. Recebendo a chancela de subgênero aclamado, "o romance histórico está na moda e a razão de tal acontecer deverá radicar tanto na apetência do público, como no retorno financeiro para as editoras e autores" (JESUS, 2015, s/p). Com esta frase, o autor João da Silva de Jesus, no seu texto intitulado "História, Pseudo-História e Romance Histórico", apresenta, em dose tripla, o auge de um subgênero literário que expande o olhar e o mercado de muitos leitores e editores portugueses. Com efeito, o fervor e o aquecimento desse subgênero são contaminados pelos modismos vigentes em relação à busca frenética pelo passado, assim como o conhecimento da própria identidade.

O texto de Jesus foi publicado pela Associação de Professores de História de Portugal $(\mathrm{APH})$ - sendo possivelmente lido pela categoria de classe. Ao que tudo indica, parece que o autor reclama uma abordagem disciplinar do entrecruzamento da História com a Literatura, transformando-as numa cadeira específica dentro das faculdades de Letras e História ${ }^{24}$. Conforme leitura, o ensaio em si não apresenta citações ou jargões acadêmicos, todavia, especula sobre a tríplice de substantivos que compõem o título. Sem apontar estatísticas, tarefa que ampliaria os horizontes do seu argumento, o artigo trabalha gradativamente a aproximação do público leitor pelo romance histórico - assim como o motivo interessado pelo real e por ser provedor de novos conhecimentos acerca da História. De acordo com o autor, poucos leitores possuem tempo para ler obras inteiras que buscam "dar vida” aos acontecimentos da História de forma longa e enciclopédica. A seu ver, a "ficção pura" não leva o interesse do leitor contemporâneo por não ter uma finalidade prática aos moldes da sociedade moderna. ${ }^{25}$ Em outras palavras, o interesse caminha para o lado do "utilitário", facilitando a vida daqueles leitores que desejam abarcar algo que os legitime como pessoas cultas e sabedoras do passado nacional. Adiante, o autor atribui à estimativa amplificativa do número de leitores pelo consumo

\footnotetext{
${ }^{24}$ No meu entendimento, a grade curricular do curso de Letras e História deve possuir uma cadeira que possa angariar estudos que iluminem esse subgênero, perfazendo seminários e grupos de pesquisas correlatos, já que ambos os cursos de graduação apresentam disciplinas pedagógicas comuns que jamais podem ser tratadas de forma compartimentada ou simplesmente estanque. Apresentando tal proposta, pode-se calcular que o tratamento de leitura do romance histórico, por parte do docente, seja de Letras ou História, proporcionará condições pedagógicas acadêmicas que permitam revelar dimensões e circunstâncias históricas as quais, brasileiros e portugueses, estão diretamente submetidos. É bem possível que o incentivo à leitura de romances históricos possa proporcionar conhecimento histórico aos alunos estudantes, afastando-os das repetitivas lembranças de decorar as datas e os fatos de forma mecanicista. Portanto, a complexidade dos fatos históricos narrados em livros, compêndios, teses e dissertações, podem ser relativizadas ao despertar maior curiosidade por parte de muitos discentes.

${ }^{25} E$ indispensável notar que as considerações acerca do interesse do romance histórico pelo público leitor vão ao encontro com às da pesquisadora Letícia Malard, no estudo Romance e história. De acordo com a autora: "A preferência por esse tipo de literatura poderia corresponder à rejeição de narrativas inventadas do nada (ainda que se tenha como certo que toda narrativa se constitui em transformação das que a antecederam) ou seja: os leitores comuns estariam perdendo o interesse por ficções originárias do imaginário/imaginação de um sujeito individualizado." (MALARD, 1996, p. 144).
} 
de romances históricos por motivos da dramatização das situações históricas facilitarem “a identificação do leitor com a narrativa” (JESUS, 2015, op. cit). Enfim, o artigo problematiza os matizes da Literatura e da História, dissolvendo brevemente a antiga problemática existente entre ambas as áreas, ampliando as motivações do leitorado na busca desse subgênero tão em voga na recém-atualidade.

No artigo "O histórico e o urbano" (1996), do pesquisador Renato Cordeiro Gomes, é possível depreender algumas reflexões acerca desse renascer do Romance Histórico Contemporâneo em terras brasileiras. Nesta pesquisa, o autor identifica no romance Boca do Inferno (1996), da cearense Ana Miranda, uma possível revigoração do Novo Romance Histórico brasileiro $^{26}$. O autor desvenda com rara originalidade que o romance histórico contemporâneo comunga com as alavancas de marketing propostas por algumas editoras específicas. De acordo com o autor, quando estamos "[...] de olho no mercado consumidor, [observamos que está] a aumentar o número de títulos do gênero", citando em nota de rodapé a importância da Editora Lê, que lançaria uma série de romances com temas da História nacional.

De igual modo, o autor também menciona a editora Companhia das Letras, Siciliano, Rocco e Rio Fundo, como empresas editoriais interessadas nesse nicho de mercado cultural. Em outras palavras, para alavancar novos leitores consumidores, é cada vez maior o investimento de muitos editores por meio de estratégias de divulgação e venda - ilustrações chamativas e comemorativas das capas de romances históricos, banners ilustrados, resenhas em jornais, noite de autógrafos, estandes em feiras de livros, lançamento de novidades, enfim são fatores determinantes na atualidade das publicações. Isto é, a abundância desses procedimentos mercadológicos favorece a expansão do mercado de romances históricos, conforme dito. Para fins de ampliação investigativa, decidi visitar o endereço eletrônico da Editora Lê, com sede na cidade de Belo Horizonte, com a finalidade de averiguarmos o catálogo de romances que a editora dispunha a respeito das narrativas históricas. Durante visita, resolvi insistir também na consulta por meio de e-mail, mas a empresa respondeu que não existem nos seus arquivos registros cujo conteúdo possa iluminar essa questão catalográfica de romances históricos publicados naquele período. ${ }^{27}$ Assim, o resultado dessa amnésia involuntária e nada agradável (formada pela ingerência de algumas editoras) é a dificuldade marcante de não termos esses dados que possivelmente gerariam diagnósticos bem produtivos. Para fins de explicação trago uma reflexão ${ }^{28}$ pertinente que parece encerrar o mote dessa discussão: "Resgatar pela

\footnotetext{
${ }^{26}$ A esse respeito, a pesquisadora Therezinha Barbieri (2003, p. 89) com a frase "mantendo-se nas paradas de sucesso por muito tempo", o romance Boca do Inferno (1996) tornou-se um grande sucesso editorial naquela época.

${ }^{27} \mathrm{O}$ correio eletrônico foi enviado no dia 10 de maio de 2014 . Com parca resposta acerca do tema, não consegui dar sequência nesta tarefa investigativa.

${ }^{28}$ Nas palavras do pesquisador Renato Cordeiro Gomes: "Desta forma, o viés que essas narrativas elegem, são as ligações, os nós, entre a literatura e a mímesis da História, tentando ler os claros que a história oficial deixou. Tecem uma história outra de que não exclui os vencidos e o cotidiano até então desprezado. De maneira muitas vezes alegórica, leem as ruínas do passado na mira do olhar do presente." (GOMES, 1996, p. 124).
} 
memória o que o esquecimento apagou parece ser a pedra de toque desses romances que, pós-modernamente, desconfiam das utopias e dos mitos gerados pelo progresso" (GOMES, 1996, p. 123). Como se vê, as reflexões desse autor são estimulantes para pensarmos que o panorama cultural brasileiro, apresentado nos últimos anos, acerca das narrativas históricas, tem se tornado discussão marcante e frequente na conjuntura cultural brasileira.

Em última análise, qualquer balanço do ressurgimento do Novo Romance Histórico brasileiro, escrito no século XXI, ligados aos artefatos de época (como foi a minha hipótese), deve levar em conta vários fatores diretos e indiretos, especialmente aqueles ligados à arte, à globalização, à geografia linguística, à tecnologia empregada nos últimos anos, à economia nacional, à cultura local, enfim, deve atentar a essas circunstâncias que balizam a formulação do próprio texto fictício. A meu ver, é nítido que o descentramento dos velhos formatos do romance histórico tradicional fez com que os novos abastecessem olhares a tais circunstâncias que cercam o homem moderno. Deve-se examinar também em que medida alguns romancistas históricos circunscritos no primeiro decênio do século XXI permearam o mapa cultural brasileiro, formulando um novo postulado desse subgênero - formando um novo público leitor.

A rigor, essa pluralidade de fatores admite algo essencial a esse subgênero: a diversidade de sua essência e a sua hibridez de formato, conquistadas nos últimos anos.

Conforme anuncia a pesquisadora Geysa Silva, no subtítulo "Nova História, novo romance" (2000), "Enveredando pelo espaço imaginário e pelo tempo subtraído da cronologia, o Romance Histórico, hoje, aponta para a sátira e para a interdisciplinaridade” (SILVA, 2000, p. 179). Em outras palavras, o crítico literário, ou o pesquisador da área deve possuir um profundo interesse às formas interdisciplinares - Cinema, Filosofia, Geografia, Ciências Sociais, Artes Plásticas, Museologia, Arquivologia, Antropologia, Fotografia -, que juntas podem revelar outras interpretações acerca desse manancial tão produtivo, conforme assinala o autor André Trouche ${ }^{29}$. O potencial dialógico marcado pelas diretrizes circunstanciais que regem cada disciplina certamente enriqueceria o manejo do subgênero, conforme dissertei acima. Travando relações com elas, preservando os estatutos vigentes, o pesquisador certamente acrescentará novas contribuições às possíveis configurações e formatações do Novo Romance Histórico Brasileiro.

Por um viés análogo, a frase "deslocar a atenção de modelos" (RESENDE, 2008, p. 15) da pesquisadora Beatriz Resende faz o efeito para assimilar esse caráter híbrido da ficção brasileira atualmente, seja ela histórica ou não, implantada no início do século XXI. Híbrido, cujo mote é atravessado por questões estéticas de vários estilos literários, tais como: crônicas, trechos filosóficos, trechos de cartas, documentos de época, trechos de livros de História, entre outros. Por esse motivo, a reivindicação das novas referências que atendam essa hibridez imposta é uma das maiores tendências, que se pode reclamar e exigir de novos autores e pesquisadores. Refletindo no mesmo sentido, tais mudanças radicais ocorridas no Brasil,

"29er: TROUCHE, André. América: história e ficção. Niterói: Eduff, 2006, p. 26. 
nos últimos tempos (já mencionadas), modificou a paisagem cultural, dificultando assim, o trabalho do escritor com o presente e o passado histórico.

\section{Algumas CONSIDERAÇÕES/PROPOSIÇões}

Ainda que tivesse uma totalidade concluída das possíveis respostas ao debate formulado na introdução desta pesquisa, eu jamais poderia subestimar uma pesquisa que pudesse responder como se opera o aspecto receptivo do Novo Romance Histórico brasileiro. Observo que é necessário realizar este tipo de investigação para que se tenha um olhar mais aprofundado sobre este tema tão instigante. A partir daí, novas teorias e formulações poderiam agregar valor de explicação ao objeto que ainda é pouco discutido e debatido, como é o caso do recente estudo contributivo (em especial o capítulo 6 - intitulado "Para que ler o romance histórico crítico no contexto da América Latina?”) realizado pelo autor Gilmei Francisco Fleck citado no decorrer desta intervenção. É importante que também se averigue como este novo modelo de público leitor se relaciona com a obra - sem meramente aderir aos rótulos motivacionais ou na aderência de identificarem as caraterísticas inerentes ao subgênero. É necessário não perder de vista que tais leitores nem sempre são avaros consumidores de artefatos de época, pois eles leem romances históricos sem a possível interface. Ao colocar alguns autores para conversarem a respeito da importância do conhecimento do passado por parte do leitor atual (a massificação das informações históricas, por meio do excesso de publicações do subgênero), nas formulações reflexivas (cada qual ao seu modo e às vezes bastante diverso, no tempo e no espaço geográfico cultural de suas origens), de Beatriz Sarlo, Andreas Huyssen, Antônio Esteves, Leticia Malard, entre outros, observo que as diferentes teses ainda se sustentam pelo motivo da febre da memória. Por um viés paralelo, reforço que a hipótese que movi ao longo do texto é que a produção de alguns artefatos de época como mero produto que chega ao consumidor final se aproxima também pelo interesse da leitura de romances históricos. Ou seja, acredito que existe um raio de influência - mesmo que este ainda seja hipotético e relativo. Obviamente que o discurso acadêmico ainda se preocupa bastante com as novas tendências que ficcionalizam a História - tais como a biografia, o discurso memorialístico, o discurso epistolar, dentre outros gêneros paralelos. Estes sequer foram objetos de investigação sobre a questão da motivação pelo público leitor na aquisição e, consequentemente, a leitura.

\section{REFERÊNCIAS}

BARTHES, R. O rumor da língua. São Paulo: Martins Fontes, 2004.

BAUDRILLARD, J. Simulacros e simulação. Lisboa: Relógio D’Água, 1981.

BURKE, P. A invenção da história. Folha de São Paulo. São Paulo, 11 set 1994, Mais. p. 6-6. 
ESTEVES, A. R. O romance histórico brasileiro contemporâneo (1975-2000). Assis: UNESP, 2010.

FLECK, G. F. O romance histórico contemporâneo de mediação: entre a tradição e $\mathbf{p}$ desconstrucionismo - releituras críticas da história pela ficção. Curitiba: CRV Editora, 2017. GARCIA, N. G. Premissas irrealistas. In: O romance histórico. Jornal de Letras. Lisboa: Artes e Ideias. Ano XXXV, n 1170/V/2015.

GOMES, R. C. O histórico e o urbano: sob o signo do estorvo. In: Revista de Literatura Comparada. Rio de Janeiro: Abralic, 2006, p. 121-131.

HALL, S. A identidade cultural na pós-modernidade. Rio de Janeiro. DP\&A Editora, 2004.

HUYSSEN, A. Seduzidos pela memória. Rio de Janeiro: Aeroplano. Museu de Arte Moderna, 2000.

HUYSSEN, A. Memórias do Modernismo. Rio de Janeiro: UFRJ, 1997.

JANSEN, T. Aventuras virtuais no passado-games abordam eras reais, despertando interesse, mas muitas vezes distorcem os fatos. Rio de Janeiro: Jornal O Globo, 2015.

JESUS, J. da S. de. História, Pseudo-História e Romance Histórico. In: Associação de professores de História. Disponível em: << http://www.aph.pt/ex_opiniao5.php>>. Acesso em: 15/09/2015. SARLO, B. Cenas da vida pós-moderna. Rio de Janeiro: UFRJ, 2005.

LOWENTHAL, D. Como conhecemos o passado. São Paulo: Projeto História (17). Tradução Lúcia Haddad, 1998.

MALARD, L. Romance e História. In: Revista Brasileira de Literatura Comparada. - N. I (1991) - Rio de Janeiro: Abralic, 1991. p. 143-151

OLIVEIRA, C. M. de. O Novo Romance Histórico em Travessias: uma leitura dos romances A República dos Bugres e Conspiração Barroca, de Ruy Reis Tapioca. 2016. 432 p. Tese de Doutorado, UFSC, Florianópolis.

OLIVEIRA, C. M. de. Relatório do Projeto. Ciclo de Palestras: Os Mestres da Narrativa Histórica Brasileira. Florianópolis: BU-UFSC, Agosto/Dezembro, 2014.

ROMANCES HISTÓRICOS BRASIL. Administradora Vânia Nunes. Facebook. Disponível em: https://www.facebook.com/groups/RomancesHistoricosBrasil/?fref=tsA Acesso em: 20-10-2014.

SEVCENKO, N. Literatura como missão. São Paulo: Brasiliense, 1988.

SCHOLLHAMMER, K. Erik. A cena do crime: violência e realismo no Brasil contemporâneo. Rio de Janeiro: Civilização Brasileira, 2013.

SILVA, K. V. SILVA, M. Henrique. Dicionário de Termos Históricos. São Paulo: Contexto, 2009. 
SILVA, G. Nova história, novo romance. In: BOECHAT, Maria Cecília Bruzzi; OLIVEIRA, Silvana Maria Pessoa de; OLIVEIRA, Paulo Motta. Romance histórico: recorrências e transformações. Belo Horizonte: FALE/UFMG, 2000, p. 179-184

STAM, R. A literatura através do cinema. Belo Horizonte: UFMG. 2008

TROUCHE, A. América: história e ficção. Niterói: Eduff, 2006.

\section{IMAGENS}

Imagem 1: Ilustrações dos jogos de tabuleiro Banco Imobiliário e Jogo da Vida - Empresa brasileira Estrela ${ }^{\circledR}$.

Imagem 2: Brinquedo eletrônico Genius - Empresa brasileira Estrela ${ }^{\circledR}$.

Imagem 3: Página inicial da comunidade "Romance Histórico Brasil", administrada por Vânia Nunes.

Imagem 4: Capas ilustrativas das revistas de Leituras da História e História da Biblioteca Nacional.

Imagem5: Foto tirada pelo autor Cristiano Mello de Oliveira. Livraria Casa Del Libro, na cidade de Madrid. Espanha. Data 25/05/2015.

Imagem 6: Foto do cartaz do evento: II Ciclo de Palestras: Os Mestres da Narrativa Histórica Brasileira. Florianópolis: BU-UFSC, Agosto/Dezembro, 2014.

Recebido para publicação 9 maio de 2019. Aceito para publicação 30 de jun. 2019. 